\title{
Notes on the Foraminiferal Genera Laterostomella De Klasz and Rérat and Streptochilus Brönnimann and Resig
}

\author{
IVAN DE KLASZ1, DICK KROON² AND JAN E. VAN HINTE ${ }^{2}$ \\ ${ }^{\prime}$ La Verdiane, 74 Av. du Mont Alban, 16300 Nice, France. \\ ${ }^{2}$ Geomarine Center, Free University, P.O. Box 7161, 1007 MC Amsterdam, The Netherlands.
}

\begin{abstract}
Laterostomella de Klasz \& Rérat (1962) and Streptochilus Brönnimann \& Resig (1971) have been described from the Miocene of Gabon and from Miocene to Recent levels of the Pacific and Indian Oceans, respectively. Both genera have since been found in the Upper Cenozoic of other regions: Laterostomella at Rockall Bank in the North Atlantic and in Papua-New-Guinea, and modern Streptochilus specimens were collected with plankton nets in the northern part of the Indian Ocean. The apertural characteristics of Laterostomella and Streptoc hilus show marked similarities as does the general shape of Laterostomella guembeliniformis with some Streptochilus species. However, other Laterostomella species have a very different form and isotopic data indicate that Laterostomella has a benthic and Streptochilus a planktic life habitat. We conclude that both genera are valid. For the first time SEM pictures of Laterostomella species are presented to show morphological variability, surface texture and aperture types.
\end{abstract}

\section{INTRODUCTION}

The principal aim of this paper is to compile the widely scattered information published on the two morphologically similar, biserial genera Laterostomella de Klasz \& Rérat and Streptochilus Brönnimann \& Resig and to update information on their stratigraphic and geographic distribution and ecology. In this way we want to elucidate possible differences between the two genera and to test the validity of their distinction. The genus Streptochilus was erected by Brönnimann \& Resig in 1971, with Bolivina tokelauae Boersma(in: Kierstad et al., 1969) as genotype. According to Resig \& Kroopnick (1983) Bolivina tokelauae Boersma is a junior synonym of Bolivina globulosa Cushman, 1933 (=Streptochilus glohulosus (Cushman)). Brönnimann \& Resig included in their genus Schwager's 1866 Textilaria globigera and described two new forms, Streptochilus latum and Streptochilus pristinum. These four species of Streptochilus should be called respectively $S$. globulosus (Cushman), $S$. globigerus (Schwager), S. latus (Brönnimann \& Resig) and S.pristinus (Brönnimann \& Resig). The genus Laterostomella created by de Klasz \& Rérat in 1962, found in Gabon (fig. 1), originally included two rather dissimilar forms: Laterostomella guembeliniformis de Klasz and Rérat and Laterostomella striata de Klasz \& Rérat, which have identical apertural features that differ from any other forms. In addition, Belford (1966) added a third species to this genus: Laterostomella voluta Belford. The new material illustrated in Plates $1-3$ herein has been filed in the collection of the Free University, Amsterdam.

\section{SYSTEMATIC PALAEONTOLOGY}

Superfamily Buliminacea Jones 1875

Family Bolivinitidae Cushman 1927

Genus Laterostomella de Klasz \& Rérat 1962

Type Species: Laterostomella guembeliniformis de Klasz \& Rérat 1962.

Description. A translation of the original French description is as follows: "A genus belonging to the family of Buliminidae with the following peculiarities. Test: biserial with more or less globular chambers, increasing regularly in size. Greatest width in the terminal portion. Sutures: strongly depressed on the genotype, less noticeable on the second species described below. Aperture: small, slightly elongated in a depression situated laterally on the apertural face. This depression is bordered on its exterior and lower margin by lips. That of the exterior margin is more developed. Its upper extremity disappears in the depression forming there a "toothplate". The lip of the lower margin is attached to the previous chamber. One of its ends disappears below the lateral lip described above. Well visible on the genotype, it is short and hardly perceptible on the other species. Ornamentation: the calcareous test is finely to rather coarsely perforate depending on the species. The ornamentation of the genotype consists of small rugosites, more developed on the initial portion of the test; that of the second species of longitudinal stripes, more or less anastomosing on the initial portion of the test. The measurements of the holotypes of the 


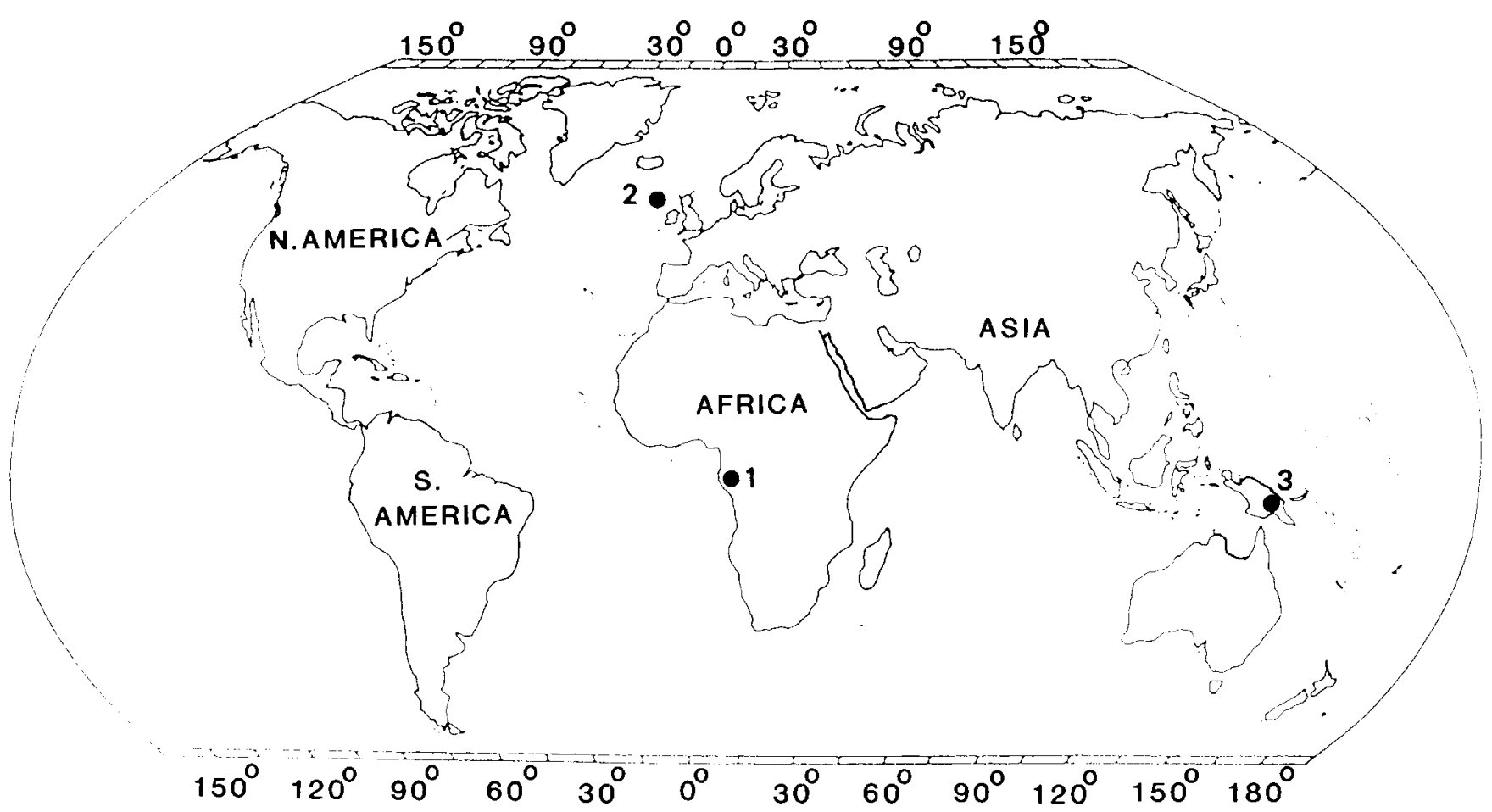

Fig. I Reported geographical occurrences of Laterostomella species: (1)Gabon; (2) Rockall Bank; (3) Papua.

two Laterostomella species described from Gabon are: $L$. guembeliniformis Length $300 \mu \mathrm{m}$; width $150 \mu \mathrm{m}$ and L. striata Length $450 \mu \mathrm{m}$; width $200 \mu \mathrm{m} . "$

Remarks: The original authors pointed out that Laterostomella differs from other genera by its very peculiar aperture. At that time Stainforthia Hofker was considered to be its closest relative. However, detailed comparison with paratypes of Virgulina concava Höglund, the genotype chosen by Hofker for Stainforthia, as well as with specimens of Stainforthia venezuelana (Nuttall) and S. dalliformis Hofker, convinced them that Laterostomella was a separate new genus. This view has been corroborated with other specialists consulted, such as Drs. Höglund, Le Calvez, Sigal and Todd.

Loeblich \& Tappan (1964) gave a short description of the genus, using the original figures of the genotype species: "Test biserial, chambers inflated, sutures depressed; wall calcareous, finely to coarsely perforate, with rugose to striate surface; aperture elongate, with bordering lip, situated in a cavity at one side of apertural face, outer margin somewhat flaring and infolded to form toothplate." These authors (1988) placed Laterostomella in the Chiloguembelinidae, but this study shows that this genus is a benthic taxon (see below).

Gabonese topotypes of L. guembeliniformis show a dense perforation, and ridges giving a cancellate appearance (Pl. 1, Figs. 9, 10). In other forms this ornamentation is attenuated and the pores are enlarged. This is probably due to dissolution, which was also observed in some Streptochilus specimens (Resig \& Kroopnick, 1983; Saito et al., 1981). Closeup pictures of the terminal part show an irregular distribution of pores on the extreme top of the last chamber. On the penultimate chambers they are sometimes aligned in very shallow furrows (Pl, 1, Fig. 12). The lip, and usually its

\section{Explanation of Plate 1 \\ Laterostomella guembeliniformis de Klasz \& Rérat 1962.}

Figs. 1, 3-12 from cutting sample 930m, Well LO15, Cap Lopez Oilfield, Gabon, Miocene Lower M'Béga Formation. Fig. 2 from cutting sample 750m, Well TC 29, N'Tchengué Oilfield, Gabon, Miocene Mandorové Formation.

Figs. 1a-c Holotype, x 70, after de Klasz \& Rérat (1962).

Figs. 2a, b Paratype, x 70, after de Klasz \& Rérat (1962).

Fig. 3. Side view of topotype, $x 165$.

Figs. 4-8 Lateral views of topotypes. All figures x 165. (Fig. 8 shows pores enlarged by solution).

Figs. 9, 10 Apertural views of topotypes, x 175, showing surface texture and imperforate apertural rim.

Fig. 11 Enlarged apertural view of specimen shown in figure 3, x 600 .

Fig. 12. Top view of topotype, $x 465$. 


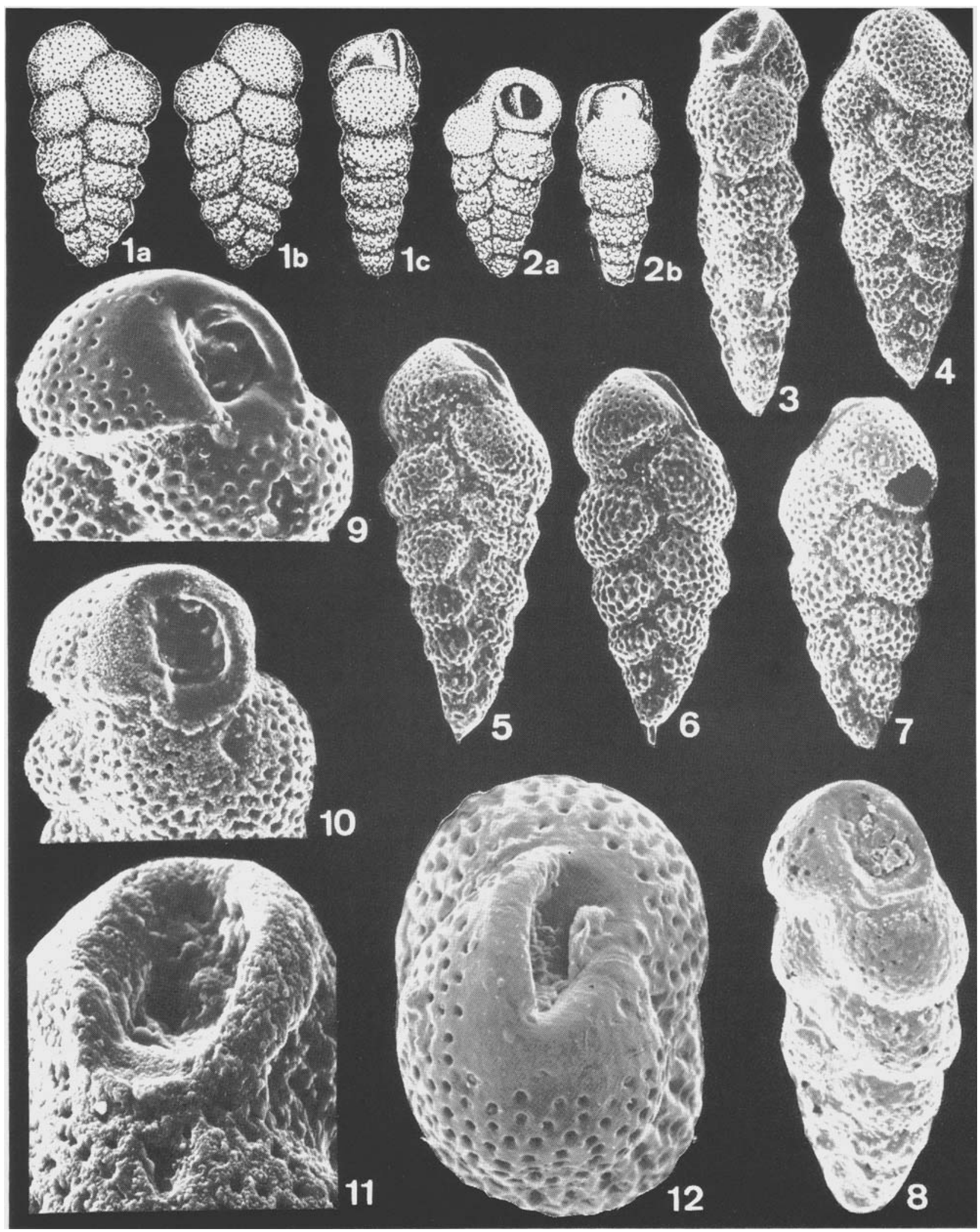


immediate vicinity, is imperforate (Pl. 1, Figs. 9, 10, 11, 12).

We also found L. guembeliniformis in DSDP Hole 116 (North Atlantic, Rockall Bank, see Fig. 1). The specimens are practically identical with the Gabonese topotypes, showing the rugose to cancellate surface texture of the holotype, and the occasional, stout basal spine (cf. Pl. 1, Fig. 6 and Pl. 2 Fig. 2).

The second Gabonese species, L. striata is characterised by 10-12 longitudinal costae, anastomosing at the early portion of the test. The test is finely perforate except for the imperforate apertural face.

A third species, L. voluta, has been described by Belford (1966) from Papua. He noted the similarity of this form with L. striata de Klasz \& Rérat from which it "differs in being twisted, less heavily ornamented and more compressed, with an oval rather than rounded outline in end view" (Belford, $1966, p .44)$. Topotypes are finely perforate, show 10-12 thin surface costae on all except the last pair of biserial chambers, and look very much like $L$. striata. They differ in being smaller and showing a strong twisting of the test. These differences in our opinion suggest that we are dealing with ecophenotypes.

Some Bolivina species may in fact belong to Laterostomella, e.g. B. suteri Cushman \& Renz. Brizalina Karreriana (Brady) as figured by Belford (1966), also shows a Laterostomella-like aperture as does more or less Cushman's (1937) figure of that species. Belford (1966) indicated that $L$. voluta resembles Bolivina yabei Takayanagi "but is more strongly twisted and more strongly costate" (Belford, 1966, p.45).

Superfamily Heterohelicacea Cushman 1927

Family Chiloguembelinidae Reiss 1963

Genus Streptochilus Brönnimann \& Resig 1971

Type Species. Bolivina tokelauae Boersma 1969 (in: Kierstad et al., 1969; = B. globulosa Cushman 1933, according to Resig \& Kroopnick, 1983).

Original description. "Test biserial sometimes twisted; wall calcareous perforate; aperture high arch, excentric in position, extending from the base of the last chamber onto the apertural face. On the outside margin a collar borders the aperture. Near the base of the inside margin, the collar and apertural edge are turned inward, producing a plate-like connection with the proximal margin of the collar of the previous aperture. The length of the test varies between 75 and 300 microns" (Brönnimann \& Resig, 1971, p. 1288).

Remarks. Although the original authors denied the existence of internal structures in near-topotypes of Chiloguembelinamidwayensis (Cushman), they remarked that the genus probably evolved from Chiloguembelina, which it resembles through infolding of the inner margin of the aperture, and that it can be classified within the Heterohelicidae. Kennett \& Srinivasan (1983) agree with Brönnimann \& Resig (1971) and Resig \& Kroopnick (1983) as far as the close relationship of Streptochilus and Chiloguembelina is concerned. They suggest that $S$. globigerus, the oldest species of the genus, directly evolved from Chiloguembelina despite the long time gap between the disappearance of the latter and the first appearance of Streptochilus.

We agree with Poore \& Gosnell (1985) who discussed the links between Chiloguembelina and Streptochilus. They indicated for Chiloguembelina that "several Upper Paleogene species have an internal apertural plate that is very similar to the internal plate typical of the Neogene genus Streptochilus while the type species of Chiloguembelina, C. midwayensis (Cushman) lacks any internal structure or modifications" (op. cit., p. 1). Their illustrations clearly show that Chiloguembelinamidwayensis midwayensis (Cushman) has an infolded apertural margin without internal plates while other species indeed do have an internal plate (i.e. S. cubensis (Palmer), $S$. martinii (Pijpers), and S. sp. aff. S. martinii) and should be assigned to Streptochilus.

\section{STRATIGRAPHIC DISTRIBUTION OF LATEROSTOMELLA}

De Klasz \& Rérat (1962) indicated "Lower to Upper Miocene" (upper part of Mandorové Formation to lower part of N'Tchengué Formation of Gabon) as the stratigraphic range for L. guembeliniformis, and "Lower Miocene": (upper part of Mandorové Formation to lower part of M'Béga Formation) for L. striata.

The genus first appears in the Gabon Basin in the Globoraotalia fohsi s.1 Zone (De Klasz \& Rérat, 1968), which is to be considered by the present biostratigraphic zonation as Middle Miocene (Blow's Zones N 9-12) (Brun \& Monteil,

\section{Explanation of Plate 2}

Figs. 1-6 Laterostomella guembeliniformis de Klasz \& Rérat from DSDP Hole 116, Rockall Bank, North Atlantic, sample $116 /$ 4/6/16-19cm, Miocene $G$. conoidea Zone.

Figs. 1a-d x 175 Lateral and side views of the same specimen. 1a-c x 175, 1d x 375 .

Figs. 2a, b Lateral and side view of a specimen with basal spine, x175. Note cancellate to rugose texture.

Figs. 3a, b Lateral and side view of broken specimen, x 175.

Fig. 3c. Enlarged top part of Fig. 3b x 600, showing aperture and internal plate.

Fig. 4 Lateral view of specimen with slightly different surface texture, x 175.

Fig. 5 Top part of a specimen showing aperture, pore free area near the aperture and randomly disposed pores on last two chambers, x 375.

Fig. 6 Enlarged partial view, showing deep seated pores causing a cancellate appearance of the lower part of the chamber, $\mathrm{x} 1500$. 


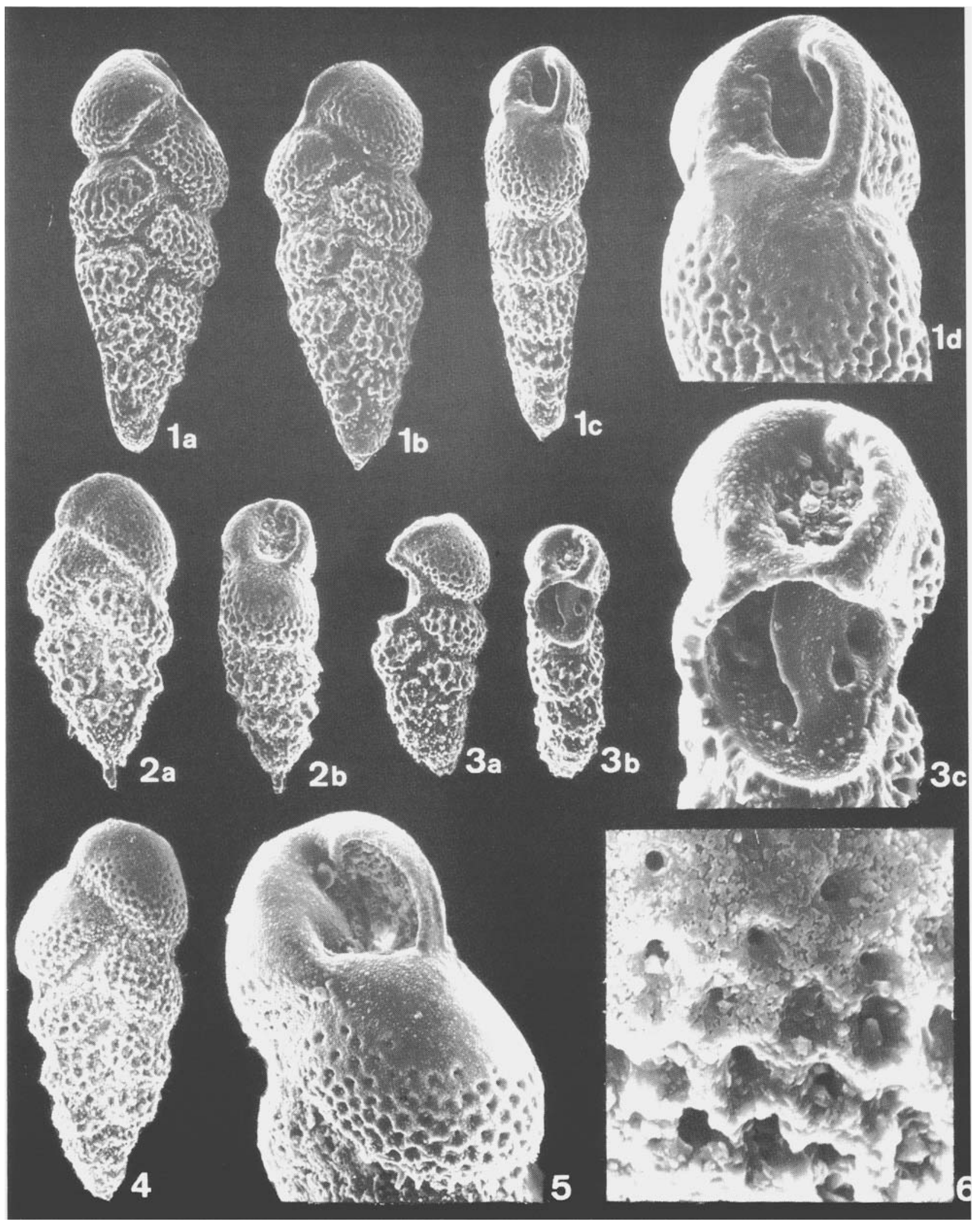




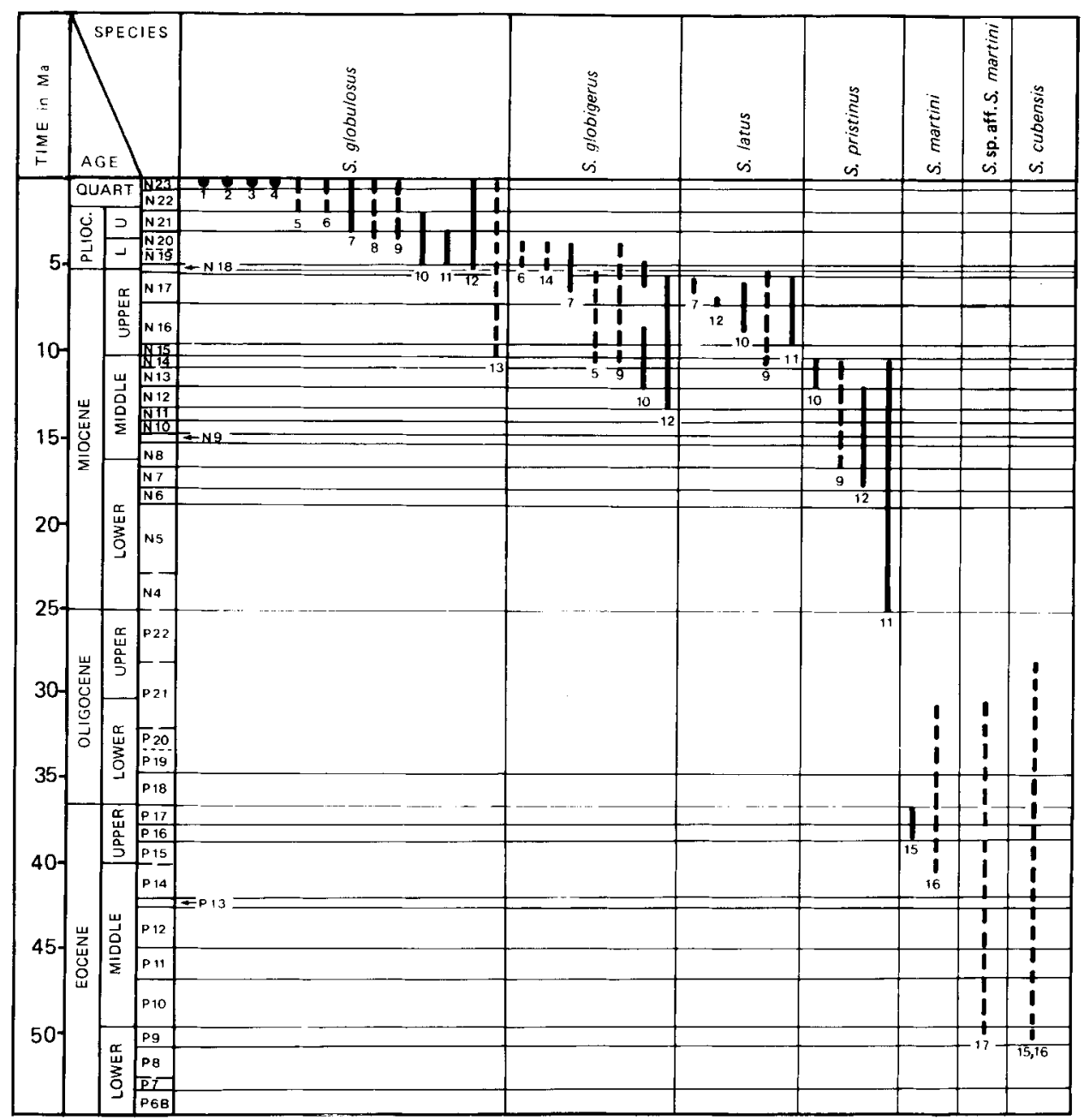

Fig. 2 Known ranges of Streptochilus species; numerical ages after Haq et al., 1987. Numbers refer to the references cited: $1=$ Kroon (1988), plankton nets 2=Cushman (1933), Central Equatorial Pacific 3=Cushman et al. (1954), Marshall Islands 4=Resig and Kroopnick (1983), Ontong Java Plateau 5=Resig et al. (1976), Solomon Islands 6=Fleisher (1974b, Red Sea (DSDP 225, 228) 7=Fleisher (1974a), Indian Ocean (DSDP 219) 8=Kierstead et al. (1969), Manihiki Plateau 9=Resig et al. (1976), Ontong Java Plateau 10=Resig and Kroopnick (1983) Eauripiki Rise 11=Resig and Kroopnick (1971) Ontong Java Plateau 12=Premoli Silva and Violanti (1981), Nauru Basin 13=Boltovskoy (1978), Indian Ocean (DSDP Sites 366, 522, 524) 14=Srinivisan et al., (1981) Fiji Islands 15=Beckmann (1957), Trinidad 16=Poore and Gosnell (1985), Atlantic Ocean (DSDP Sites 366, 522, 524); Pacific (DSDP Sites 317, 577; Gulf of Mexico (Eureka core E67-128) 17=Poore and Gosnell (1985), Pacific (DSDP Site 37); Gulf of Mexico (Eureka core E67-128).

\section{Explanation of Plate 3}

\section{Laterostomella striata de Klasz \& Rérat 1962}

Figs. 1-7 from sample 910m. Well TC 36, N'Tchengué Oil field, Gabon, Miocene Mandorové Formation.

Figs. 8-9 From Murua Mudstone, Malalua-Saw Mountains area, Papua.

Figs. 1a-c Laterostomella striata de Klasz \& Rérat, holotype, after de Klasz \& Rérat 1962, x70.

Fig. 2 Laterostomella striata de Klasz \& Rérat, paratype, after de Klasz \& Rérat, x 70.

Fig. 3 Laterostomella striata de Klasz \& Rérat, topotype, x 165.

Fig. 4 Laterostomella striata de Klasz \& Rérat, topotype, $\mathrm{x} 90$.

Fig. 5 Aperture of specimen shown in fig. $4, \times 600$.

Fig. 6 Aperture of specimen shown in fig. $3, x 600$.

Fig. 7 Aperture of Gabonese topotype, $x 600$.

Fig. 8 Laterostomella striata de Klasz \& Rérat (=ecophenotype L. voluta Belford), x 260.

Fig. 9 Laterostomella striata de Klasz \& Rérat (=ecophenotype L. voluta Belford), specimen showing internal plate, x 305. 


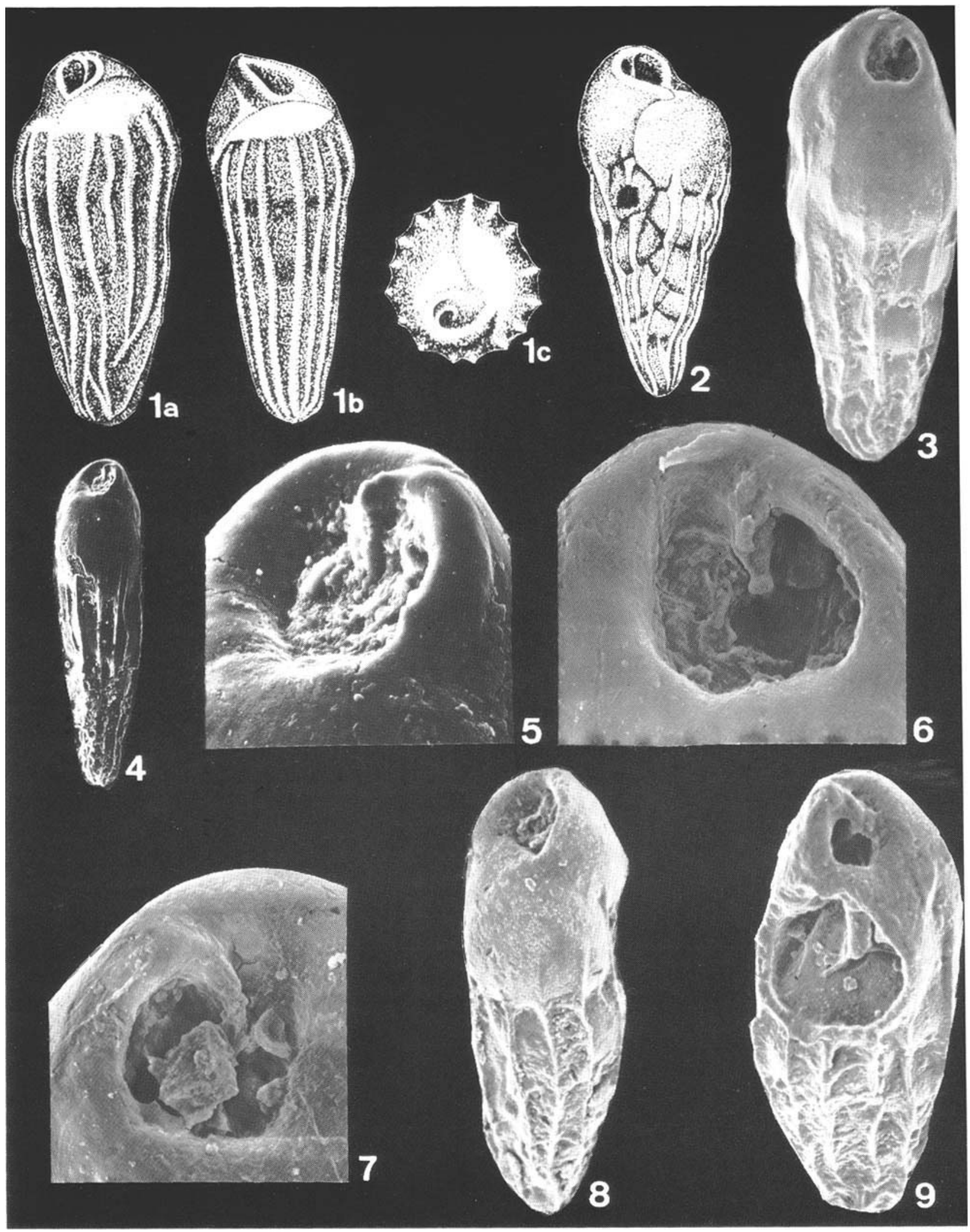


1974; Berggren et al., 1985; Bolli et al., 1985; Haq et al., 1987). The upper limit of the stratigraphic range of $L$. guembeliniformis is in the lower part of the N'Tchengue Formation which has been dated as Late Miocene to Pliocene on the basis of planktic foraminifera (Brun \& Monteil, 1974), and ostracods (Van den Bold in de Klasz et al., 1978). In Gabon L. guembeliniformis is thus ranging from the Middle Miocene to the Upper Miocene if not even to the lowermost Pliocene.

In DSDP Hole 116 L. guembeliniformis specimens are abundant in the Upper Miocene ( $G$. conoidea Zone, sample $116 / 4 / 6 / 16-19 \mathrm{~cm})$. The top of the range of $L$. striata in Gabon is in the lower part of the M'Béga Formation at the top or just above the Globorotalia fohsi group Zones. Its age is therefore late Middle Miocene or early Late Miocene. This corresponds to van den Bold's Tortonian age determination based on ostracods (in: de Klasz et al., 1978).

Belford (1966) found Laterostomella striata (=phenotype L. voluta) in the Murua Mudstone from the MalalauaSaw Mountains area of Papua in levels ranging from Burdigalian to Pliocene in age.

\section{STRATIGRAPHIC DISTRIBUTION OF STREPTOCHILUS}

In Figure 2 we used the Haq et al. (1987) time scale as a reference for the Streptochilus species ranges according to different authors.

\section{ECOLOGIC INTERPRETATION}

De Klasz \& Rérat (1962) considered Laterostomella a benthic genus with $L$. striata as a "typical" benthic form while L. guembeliniformis has strong morphological similarities with biserial planktic genera like Heterohelix, Chiloguembelina and Streptochilus. There are however intuitive arguments in favour of the benthic way of life of $L$. guembeliniformis. For instance, a stout spine at the base of the test is found in many benthic species but never in biserial forms of known planktic habitat. The fact that laterostomella has not been found in deep water sediments is further argument for such a habitat.

In Gabon both species are found in a mixed benthicplanktic foraminiferal assemblage, with benthics dominating. The fauna has been interpreted to represent Upper Slope to Outer Shelf conditions (de Klasz \& Rérat, 1968). The depth of deposition of the Miocene at DSDP Site 116 is approximately 1200m (Berggren, 1972).

The most decisive evidence for the benthic nature of $L$. guembeliniformis has been provided by stable oxygen isotope analysis of DSDP Hole 116 core material. The $\delta^{18} 0$ value for L. guembeliniformis compare with the benthic and not with the planktic assemblage of the same sample (see Table 1). The difference with $\delta^{18} 0$ of planktic forms is considerable and allows $L$ guembeliniformis to be classified clearly as a benthic form. Loeblich and Tappan (1988) thus erroneously included the genus Laterostomella in the family

\section{Explanation of Plate 4}

Figs. 1a-b Streptochilus globulosus (Cushman), holotype, Recent, Tropical Pacific, after Cushman $1937, x 55$.

Figs. 2a-c, Streptochilus globulosus (Cushman), Equatorial Pacific near Tokelau Island, Core V 18-262, Pleistocene. Size indicated by scale bar, after Boersma 1969 (in: Kierstead et al.).

Figs. 3 \& 4 Streptochilus globulosus (Cushman), Fig. 3 DSDP Site 61.1/7/1/109-1 lcm, Late Pleistocene (N 21), x 245. Fig. 4 , DSDP Site 61.1/11/1/109-11 cm, Early Pliocene (N19), x216. After Resig and Kroopnick (1983, pl.1, figs. 3,4).

Fig. 5 Streptochilus globulosus (Cushman), upper part of test showing internal plate, S. 67-FFC 25, Late Quaternary. After Resig \& Kroopnick (1983, pl. 1. fig. 1), x 744.

Figs. 6a-b, Streptochilus globulosus (Cushman), Ontong Java Plateau, Hawaii Inst. Geophys. Core 67-27, Late Quaternary. After Brönnimann \& Resig (1971, pl. 51, fig. 1), x 400.

Figs. 7 -9 Streptochilus pristinus Brönnimann \& Resig, Fig. 7 Holotype. Ontong Java Plateau, x 500. after Brönnimann \& Resig (1971, pl. 51, fig. 4). Fig. 8. DSDP Site 62.1/34/2.109-111cm., Middle Miocene (N 13), x 162. After Resig and Kroopnick (1983), pl. 1, fig. 19) Fig. 9 DSDP Site 62.1/34/2/109-111 cm, Middle Miocene (N13), x 210, side view. After Resig \& Kroopnick (1983, pl. 1, fig. 20).

Fig. 10 Streptochilus latus Brönnimann \& Resig, DSDP. Site 62.1/25CC, Late Miocene (N16). After Resig and Kroopnick (1983, pl. 1, fig. 7), x220.

Fig. 11 Streptochilus globigerus (Schwager) holotype, Car Nicobar Island, Bay of Bengal, Miocene, x 180. After Schwager (1866).

Figs. 12 \& 13 Streptochilus globigerus (Schwager), Fig. 12, DSDP. Site 62.1/16/1/109-11 cm x 194. Late Miocene (N17) Fig. 13, DSDP Site 62.1/16/109-11 cm, x 252, Late Miocene (N 16), side view showing interior of last chamber and apertural plate. After Resig \& Kroopnick (1983, pl. 1, figs. 11, 15).

Fig. 14 Streptochilus martini (Pijpers), DSDP Site 522/37CC, Upper Eocene, lateral view, x 166. After Poore \& Gosnell (1985, pl. 1, fig. 1).

Fig. 15 Streptochilus sp. aff. S. martini (Pijpers), DSDP. Site 317 B 39/5/90-93cm, Middle Eocene, side view, x 200. After Poore \& Gosnell (1985, pl. 1, fig. 13). 


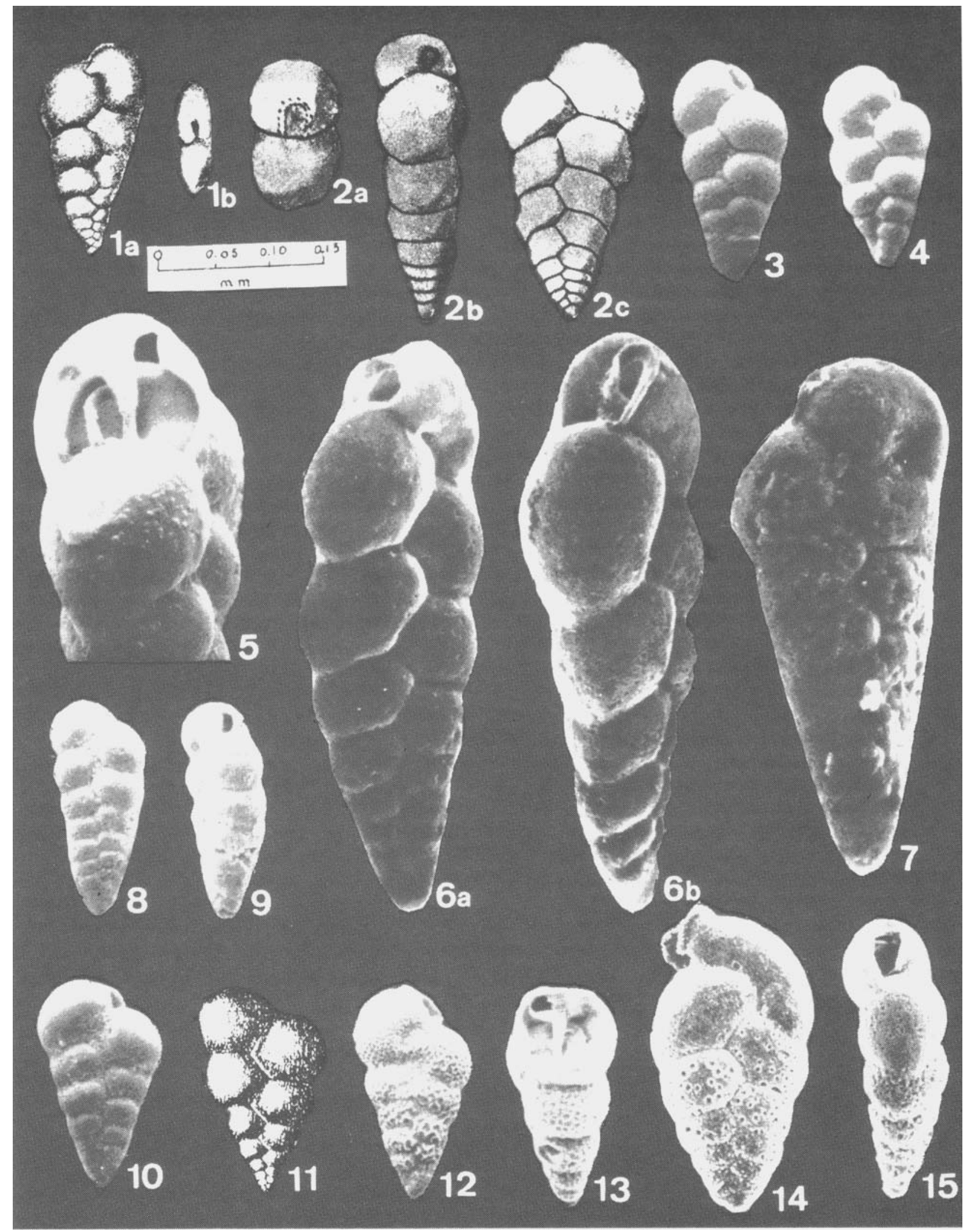




\begin{tabular}{ll}
\hline Species & $\delta^{18} 0$ \\
\hline Laterostomella guembeliniformis & 2.16 \\
Cibicides sp. & 2.17 \\
Gyroidinoides sp. & 2.35 \\
Neogloboquadrina acostaensis & 1.42 \\
\hline
\end{tabular}

Table $1 \delta^{18} 0$ values in $\%$ (PDB) measured both planktic and benthic species from Site 116: core 4, section 6, 16-19 $\mathrm{cm}$ (Late Miocene).

Heterohelicidae Cushman.

Brönnimann \& Resig (1971) considered Streptochilus as planktic forms because of their morphologic similarities to Heterohelix and Chiloguembelina and also because of "the absence in assemblages affected by differential solution, as opposed to the concentration in those assemblages of undisputed deep water benthic species" (op. cit., p. 1264). Because they had not been reported in oceanic plankton tows, despite their presence in sub Recent deposits as determined by ${ }^{14} \mathrm{C}$ dates. Brönnimann and Resig (1971) considered the possibility that Streptochilus became extinct. Isotopic and distributional evidence further convinced Resig \& Kroopnick (1983) of the planktic life habit of Streptochilus.

We found Streptochilus in plankton tows from the northern Indian Ocean (D. Kroon, pers. comm.) ascertaining that the genus is a persistent constituent of world ocean plankton.

\section{CONCLUSIONS}

1. Literature and our own studies show that Laterostomella de Klasz \& Rérat 1962 and Streptochilus Brönnimann \& Resig 1971, are indeed separate genera.

2. Stable oxygen isotope measurements on the genotype L. guembeliniformis show that Laterostomella is a benthic genus, in spite of morphological similarities with planktic Streptochilus species. Thus Streptochilus should not be included in Laterostomella as has been done by Loeblich and Tappan (1988).

3. Laterostomella voluta Belford is in our opinion a phenotype of L. striata de Klasz \& Rérat.

4. The range of Laterostomella guembeliniformis given in the original description should be changed to Middle Miocene-Late Miocene (possibly even earliest Pliocene), from Early-Late Miocene. The range of $L$. striata is early to late Middle Miocene, possibly reaching into the early part of the Late Miocene.

5. The planktic habitat of Streptochilus is evident and collections of extant Streptochilus in the Indian Ocean prove that the genus is still very much alive.

6. We agree with Poore \& Gosnell (1985) to include Upper Paleogene species in Streptochilus. These forms may have derived from Paleogene Chiloguembelina.

7. The possibility that some bolivinid species such as Bolivina suteri, Bolivina yabei and Brizalina karreriana, as figured by Belford (1966), belong to Laterostomella, should be examined with the help of type material.

\section{ACKNOWLEDGEMENTS}

We thank D. J. Belford, J. P. Kennett and J. M. Resig for their advice and sending us material. This study was supported by the Netherlands Organisation for the Advancement of Pure Research (ZWO, AWON, 76-84, URG). This paper is contribution nr. 26 of the Geomarine Center, Amsterdam.

\section{Manuscript Received February 1989, Accepted July 1989.}

\section{REFERENCES}

Beckmann, J.P., 1957. Chiloguembelina Loeblich and Tappan and related foraminifera from the lower Tertiary of Trinidad, B.W.I: U.S. Nat. Mus. Bull., 215, 83-95.

Belford, D.J., 1966. Miocene and Pliocene foraminifera from Papua and New Guinea, Dept. Nat. Dev. Bur. Min. Res. Geol. and Geophys. Bull., 79, 306.

Berggren, W.A., 1972. Cenozoic biostratigraphy and paleobiogeography of the North Atlantic. In: A.S. Laughton and W.A. Berggren et al., Initial Reports of the Deep Sea Drilling Project, Vol. 12, U.S. Govt. Printing Office, Washington D.C., 965-1002.

Berggren, W.A., Kent, D.V., Flynn and van Couvering, J.A., 1985. The Neogene: Part 2, Neogene geochronology and chronostratigraphy. In: Snelling, N.J. The chronology of the geological record. The Geological Society. Black well Scientific Publications, 211-260.

Bolli, H.M., Saunders J. B., and Perch-Nielsen K., 1985. Plankton Stratigraphy. Cambridge University Press, Cambridge, 1-1032.

Boltovskoy, E., 1978. Late Cenozoic benthonic foraminifera of the Ninetyeast Ridge (Indian Ocean). Mar. Geol., 26 139-175.

Brönnimann, P. and Resig, J., 1971. A Neogene globigerinacean biostratigraphic time-scale of the southwestern Pacific. In: Winterer, E.L, et al., Initial Reports of the Deep Sea Drilling Project, Vol.7, U.S. Government Printing Office, Washington, D.C., 1235-1469.

Brun, J.A.L., and Monteil, L., 1974. Principaux foraminifères pélagiques du Néogene due Gabon, Unpubl. re. ELFR.E., 1-5.

Cushman, J.A., 1933. Some new Recent foraminifera from the tropical Pacific. Contr. Cushman Lab.Foram.Res., 9 , 80.

Cushman, J.A., 1937. A monograph of the subfamily Virgulinidae of the foraminiferal family Buliminidae, Cushman Lab. Foram. Res., Spec. Publ., 9, 1-225.

Cushman, J.A., Todd, R., and Post, R.J., 1954. Recent foraminifera of the Marshall Islands. U.S. Geol. Surv. Prof. Pap., 260-H, 319-384.

Fleisher, R.L., 1974a. Cenozoic planktonic foraminifera and biostratigraphy, Arabian Sea, In: Whitmarsh et al., Initial 
Reports of the Deep Sea Drilling Project, 23 U.S. Government Printing Office, Washington D.C., 1001 1072.

Fleisher, R.L. 1974b. Preliminary report on late Neogene Red Sea Foraminifera Deep Sea Drilling Project, Leg 23B. In: Ludendijk, P.B. and Davis, T.A., Initial Reports of the Deep Sea Drilling Project, U.S. Government Printing Office, Washington D.C. 985-1012.

Haq B.U., Hardenbol J. and Vail P.R., 1987. Chronology of fluctuating sealevels since the Triassic. Science, 11651167.

Kennett, J.P. and Srinivasan, M.S., 1983. Neogene Planktonic Foraminifera. A phylogenetic Atlas. Hutchinson Ross Publ. Co., Stroudsburg, Pennsylvania, 1-261.

Kierstead, C. H., Leidy, R., Fleisher, R.L. and Boersma, A., 1969. Neogene zonation of tropical Pacific cores. In: P. Brönnimann and H.H. Renz (Editors). Proc. First Int. Conf. Planktonic Microfossils, Geneva, 1967, Brill, Leiden, Vol.2, 328-338.

Klasz, I. de and Rérat, D., 1962, Quelques nouveaux foraminifères du Crétacé et due Tertiaire due Gabon (Afrique Equatoriale. Rev. Micropaleontol. 4 (4) 175 189.

Klasz, I. de, Rérat, D., 1968, Principaux Foraminifères du Bassin Gabonais, Internal Rep., Elf Gabon, RI, 18-45.

Klasz, I. de, Micholet, J. and Wenger, R., 1978, Mise a jour et complément concernant la stratigraphie du bassin côtier gabonais. Actes VI Coll. Afr. Micropaleontol., Tunis, 1974, Aun, Mines Geol. Tunis, 28, 7-29.

Loeblich, A.R. and Tappan, H., 1964, Protista 2, Sarcodina, Chiefly 'Thecamoebians' and Foraminiferida. Part C. In: Treatise on Invertebrate Paleontology (Moore R.C. ed.), 2 vols. Geol. Soc. Amer. and Univ. - Kansas Press, 900.
Loeblich, A.R. and Tappan, H., 1988. Foraminiferal Genera and their Classification. Van Nostrand Reinhold Company, New York, 1-970

Poore, R. Z., and Gosnell, L.B., 1985, Apertural features and surface texture of Upper Paleogene biserial planktonic foraminifers; links between Chiloguembelina and Streptochilus, J. Foram. Res., 15, 1-5.

Premoli Silva, I. and Violanti, D., 1981. Cenozoic planktonic foraminifer biostratigraphy of Deep Sea Drilling Project Hole 462, Nauru Basin (Western Equatorial Pacific), and distribution of the pelagic components. In: Larson et al., Initial Reports of the Deep Sea Drilling Project, 61, U.S. Government Printing Office, Washington, D.C., 397422.

Resig, J.M., Buyannanonth, V. and Roy, K.J., 1976. Foraminiferal stratigraphy and depositional history in the area of the Ontong Java Plateau, Deep Sea Research, 23 441-456.

Resig. J.M. and Kroopnick, P.M., 1983, Isotopic and distributional evidence of a planktonic habit for the foraminiferal genus Streptochilus Brönnimann and Resig; 1971, Mar. Micropal., 8, 235-248.

Schwager, C., 1866, Fossile Foraminiferen von Kar Nikobar, Novara Expedition, Geol, 2 187-268.

Saito, T., Thompson, P.R. and Breger D., 1981. Systematic index of Recent and Pleistocene Foraminifera, Univ. Tokyo Press, 1-190.

Srinivisan, M.S., Kennett, J.P. and Rodda, P., 1981. Late Neogene planktonic foraminiferal biostratigraphy, Suva, Fiji, J. Paleontol., 55, 858-867. 